\author{
Dr. sc. Neven Šimac
}

\title{
PRAVO NA DOBRU JAVNU UPRAVU - u kontekstu europskih integracija -
}

\author{
UDK: 352/354 (44) \\ Izvorni znanstveni rad \\ Primljeno: 15. IX: 2015.
}

\begin{abstract}
Ovaj naslov podsjeća neminovno na ljudska prava i kao da inzistira na nekom novom pravu čovjeka i građanina, poput npr. „prava na vodu“, koje je bilo predmetom građanske zakonotvorne inicijative prošle godine pred Europskom komisijom.

Pravo na „dobru javnu upravu“ često se poistovjećuje s pravom na „dobro upravljanje“, pa će stoga u uvodnom dijelu biti potrebno razjasniti razliku između tih dvaju pojmova, te se potom pozabaviti „dobrom javnom upravom“, njezinim načelima i deontologijom u dvjema europskim integracijama - članice koje su i Hrvatska i Francuska - a to su, najprije ona starija, politička integracija Vijeća Europe, a zatim i ona malo mlađa, još uvijek pretežito ekonomska integracija, a to je Europska unija. Promotrimo stoga najprije što ta dva pojma znače u međunarodnim organizacijama, a što na internom planu demokratskih država.
\end{abstract}

Ključne riječi: Pravo na dobru upravu, europske integracije, države članice

\section{UVOD:}

\section{DOBRO UPRAVLJANJE I DOBRA JAVNA UPRAVA}

1. Pojam „,dobrog upravljanja“ nalazi se već kod Aristotela i njegova opisa države kojom upravlja etičan i pravedan vladar. Pojam, međutim, oživljuje u novije doba, kad ga se rabi u kontekstu donošenja odluka i njihova provođenja na međunarodnoj, nacionalnoj i lokalnoj razini. ${ }^{1}$

Zanimljivo je da pojam „dobrog upravljanja“ - bonne gouvernance / good governance - nije vlastitost javne sfere, premda ga se vezuje i za javne poslove. Isto tako ga se nužno ne vezuje za demokratske države i sustave, nego ga se, $\mathrm{s}$ jedne strane, rabi za donošenje odluka i njihovo provođenje u privatnom sektoru, a s druge ga se vezuje za ekonomsku sferu i dobro upravljanje „razvojem nerazvijenih država“. ${ }^{2}$ Pojam je taj, dakle, evoluirao i postajao sve više ne-pravni, gotovo samo pitanje „tehnike“, koji ne uključuje nužno ni demokraciju, ni javni interes. Kao takav, on se ne pojavljuje u ustavima i pravnim sustavima država članica (DČ) Vijeća Europe (VE) i Europske unije (EU).

S druge pak strane, „dobra javna uprava“ jest pravni i ustavni pojam koji se temelji na jasno određenim postupovnim načelima i pravilima, kao i na

1 V. dokument Europske komisije za demokraciju putem prava (tzv. Venecijanska komisija) CDL-AD (2011.) 009m Strasbourg, 8. travnja 2011., pod naslovom Bilan sur les notions de „bonne gouvernance“ et de ,bonne administration “.

2 Tako Svjetska banka; v. supra, p. 3-4. 
deontologiji javne uprave. Bez obzira na tu značajnu razliku, pojam „dobrog upravljanja“ (DU) susrećemo, ali često u različitim značenjima i kontekstima, i u dokumentima VE i EU. DU nalazimo u dokumentima VE, gotovo kao sinonim „dobre javne uprave“33 (DJU). Nalazimo je u rezolucijama i preporukama Vijeća ministara VE i Parlamentarne skupštine, npr. u sportu, pa i kao generički pojam koji uključuje demokraciju, ljudska prava, socijalne reforme, pa čak i ekonomske reforme po tržišnim načelima... ali uvijek bez ikakve precizne definicije. ${ }^{4}$

$\mathrm{Na}$ precizniju definiciju se ipak odlučuje (ondašnja) Europska zajednica u jednom međunarodnom ugovoru iz 2000. godine kad ovako određuje DU: „transparentno i odgovorno upravljanje ljudskim, prirodnim, gospodarskim i financijskim resursima s ciljem pravičnog i održivog razvoja. Ona uključuje jasne postupke odlučivanja javnih vlasti, institucije transparentne i obvezne polagati račune, prvenstvo prava u upravljanju i raspodjeli resursa, kao i ojačanje sposobnosti za donošenje i provođenje mjera, posebice što se tiče prevencije i borbe protiv korupcije. ${ }^{\text {" }}$ Europska komisija isto tako u to vrijeme (2001.) definira u svojoj Bijeloj knjizi o europskom upravljanju pet načela DU: otvorenost, sudjelovanje, odgovornost, učinkovitost i koherentnost" ${ }^{6}$

Dodajmo ovdje još samo to da i Organizacija ujedinjenih naroda u brojnim dokumentima, navlastito što se tiče razvoja zemalja, inzistira na DU i definira ga na vrlo različite i široko postavljane načine. Slično postupa i Međunarodni monetarni fond, kao i velike kontinentalne razvojne banke. ${ }^{7}$

2. Pojma ,dobre javne uprave“ (DJU) nema ni u kojem od ugovora VU, ali neke konvencije VU-a ukazuju i štite pojedine aspekte DJU. Tako Europska konvencija o ljudskim pravima, navlastito u čl. 6, ali i Europski sud ljudskih prava u svojim presudama utvrđuju pravo na dobru upravu pravosuđa. ${ }^{8} \mathrm{Na}$ zahtjev Parlamentarne skupštine VE, Vijeće ministara je 2007. godine objavilo Preporuku, kojoj je priložilo model „kodeksa DJU“ i devet načela DJU: zakonitost, jednakost, nepristranost, razmjernost, pravna sigurnost, razuman rok za djelovanje /JU/, sudjelovanje, poštovanje privatnog života i transparentnost. ${ }^{9}$

Europska unija je pak tek u novije vrijeme i to u svom primarnom pravu, u Lisabonskom ugovoru (2009.), točnije u čl. 41. Povelje temeljnih prava, proklamirala „Pravo na dobru javnu upravu“ i precizno ga definirala, što će biti predmetom drugog dijela ovog prikaza. Tabela koja slijedi prikazuje usporedno

3 Sastanak na vrhu šefova država i vlada VE u Varšavi 2005. godine.

4 U dokumentu bilješke pod 1 , na str. 5 .

5 Čl. 9/3 Ugovor u Cotonou, EZ sa Skupinom država Afrike, Kariba i Tihog oceana.

6 Dokument COM (2001.) 428 final, str. 12.

V. dokument naveden pod bilješkom 1, str. 8-13.

8 Definiciji DJU pridonosi i Konvencija VE za zaštitu osoba kod elektronskog obrađivanja podataka osobne naravi.

$9 \mathrm{CM} / \operatorname{Rec}(2007) 7$. 
načela koja bi trebala, odnosno koja stvarno - oko kojih postoji pretežito suglasje - karakteriziraju i jedan i drugi pojam: ${ }^{10}$

\begin{tabular}{|l|l|}
\hline \multicolumn{1}{|c|}{ DOBRO UPRAVLJANJE } & \multicolumn{1}{c|}{ DOBRA JAVNA UPRAVA } \\
\hline & Nepristranost \\
\hline & Pravna sigurnost \\
\hline & Razmjernost \\
\hline Odgovornost & Nediskriminacija \\
\hline Transparentnost & Pravo biti saslušan \\
\hline Sposobnost odgovoriti potrebama građana & \\
\hline Učinkovitost & Učinkovitost \\
\hline Djelotvornost & Djelotvornost \\
\hline Otvorenost & \\
\hline Sudjelovanje & \\
\hline Predvidivost & \\
\hline Pravna država & \\
\hline Koherentnost & \\
\hline Pravičnost & Pravičnost \\
\hline Etičko ponašanje & \\
\hline Borba protiv korupcije & \\
\hline Dovršetak postupaka u razumnom roku & Dovršetak postupaka u razumnom roku \\
\hline Zaštita ljudskih prava & \\
\hline Pojednostavljivanje postupaka & \\
\hline
\end{tabular}

Završne konstatacije:

- od 16 načela DU, samo 4 su istovjetna s načelima DJU, dok ih je 12 specifično za DU;

- od 9 načela DJU, 5 ih je vlastito DJU, a samo 4 su zajednička s načelima DU.

$\boldsymbol{U}$ zaključku ovog Uvoda moguće je ustanoviti da je pojam DU, u njegovoj današnjoj međunarodnoj uporabi, s jedne strane neodređen, nejasan, „maglovit““ i daleko širi od pojma DJU, a s druge on izlazi iz pravne i ustavne sfere i smješta se i u druga područja, a katkad poprima i ideološke, liberalne, pače neoliberalne naglaske. Najčešće nije jasno radi li se u slučaju DU o sredstvu da bi se postigao određeni cilj, ili pak o samom cilju.

Pojam DU katkad uključuje i DJU, ali njegova pretežito izvanpravnog značenja nema ni u ugovorima VE ni EU, a ni u nacionalnim pravnim porecima. Obrnuto je pravilo što se tiče DJU, najprije u nacionalnim pravnim sustavima, gdje ona postoji kao načelo, ali rjeđe baš tako navedena, kao i u dvjema osnovnim

10 V. dokument naveden u bilješci 1, str. 18-19. 
europskim integracijama - VE i EU, pa pogledajmo kako ove integracije (a to je središnji predmet ovog izlaganja) definiraju i koji sadržaj određuju pojmu DJU što, povratno, u određenoj mjeri utječe i usmjerava i njihove DČ.

DJU postoji, naime, kao načelo, ne kao izravno provedivo, već kao složeno načelo i pravo koje je precizno razrađeno u više konkretnih prava i obveza. DJU podrazumijeva i uključuje ne samo temeljna načela, nego i postupovna pravila i jamstva, kao i deontološke regule javne uprave.

\section{DIO: \\ DOBRA JAVNA UPRAVA U PRAVNOM „PROSTORU“ VIJEĆA EUROPE}

Već je spomenuto da u najvećem dijelu konvencija i protokola $\mathrm{VE}^{11}$ - koje je politička i pravna integracija država - ne figurira pravo na DJU. Ono se pojavljuje, međutim, ne samo u temeljnoj Europskoj konvenciji o ljudskim pravima i vrlo malom broju drugih konvencija i protokola, nego i u brojnim preporukama i rezolucijama VE, ali najpotpunije u navedenoj Preporuci Vijeća ministara državama /članicama/ koja se odnosi na dobru javnu upravu, ${ }^{12}$ kojom VE traži od svojih 47 DČ:

- da promiču DJU kao dio načela pravne države i demokracije;

- da promiču DJU kroz organizaciju i funkcioniranje koji osiguravaju djelotvornost, učinkovitost $i$ razborito trošenje javnih sredstava; te

- da promiču pravo na DJU koje je u interesu svih, koristeći se normama sadržanima u modelu kodeksa koji je priložen ovoj Preporuci.

Ovaj se Kodeks VE sastoji od uvodnih odredaba i tri dijela. Uvodne odredbe omeđuju područje primjene Kodeksa, prvi dio navodi devet osnovnih načela DJU, a drugi dio određuje pravila za upravne akte, dok završni, treći dio, tretira pravo utoka / priziva i naknade štete za nezakonite upravne akte.

Uvodni dio precizira pojam javne uprave i njegove dvije sastavnice:

svako javno-pravno tijelo... a posebice državu, lokalne zajednice, samostalna upravna tijela koja obavljaju funkcije javnih usluga ili od javnog interesa;

svako tijelo privatnog prava kojem su dodijeljene ovlasti javne vlasti za obavljanje funkcija javnih usluga ili od javnog interesa.

Za razliku od ovih, Kodeks VE određuje kao „privatne osobe“ sve fizičke i pravne osobe koje su korisnici djelovanja javno-pravnih tijela.

11216 ukupno do 25. ožujka 2015. godine. V. portal VE: www.coe.int

$12 \mathrm{CM} / \mathrm{Rec}$ (2007.) 7 od 29. listopada 2008. 
U prvom dijelu, Kodeks VE navodi sljedećih devet načela DJU:

- zakonitosti, koje obuhvaća i interno i međunarodno pravo, i to kao branu protiv svake arbitrarne mjere, čak i u obavljanju diskrecijskih ovlasti;

- jednakosti, odnosno nediskriminacije, bez obzira na bilo koju pripadnost;

- nepristranosti, odnosno objektivnosti, bez obzira na uvjerenja i osobne interese javnih službenika;

- razmjernosti u određivanju mjera koje su neophodne i podobne postići zadani cilj, a koje nisu pretjerane, tj. koje su pravična mjera između traženog javnog cilja i prava i interesa privatnih osoba;

- pravne sigurnosti, u skladu s kojom se, s jedne strane, ne ugrožavaju stečena prava (osim u javnom interesu), a s druge ne donosi retroaktivne mjere, osim iznimno, kad je to zakonito opravdano;

- razumnog roka za djelovanje javne uprave;

- odgovarajućeg sudjelovanja privatnih osoba u pripremi $i$ primjeni svih upravnih akata koji ih se tiču;

- poštovanja privatnog života / privatnosti, navlastito kad se radi o elektroničkim podacima;

- transparentnosti djelovanja JU i dostupnosti javnim dokumentima, osim u slučajevima legitimne tajnosti podataka. tako:

Drugi dio Kodeksa VE tretira jedanaest pitanja „rě̌ima“ upravnih akata, pa

- najprije definira upravne akte, kao opće i pojedinačne;

- zatim određuje da inicijativa za donošenje upravnih akata može dolaziti i od JU i od privatnih osoba;

- kad se radi o zahtjevu privatne osobe za donošenje neke upravne odluke, onda JU mora odgovoriti u razumnom roku na svaki takav zahtjev i naznačiti rok koji je potreban za to, te mora postojati pravo utoka kad JU tako ne postupi; osim toga, ako je koja takva inicijativa upućena nenadležnoj JU, ona je mora proslijediti nadležnoj instituciji;

- određuje pravo privatnih osoba da budu saslušane u razumnom roku u stvarima svojih pojedinačnih upravnih akata - same ili uz pomoć druge osobe po vlastitom izboru - navlastito u slučajevima kad upravni akt može utjecati na njihove interese ili biti za njih nepovoljan;

- precizira pravo privatnih osoba da sudjeluju - opaskama, javnim očitovanjem, kroz savjetodavna tijela... - u donošenju nekog pojedinačnog akta koji može utjecati na situaciju neodređenog broja osoba;

- određuje da trošak / cijena / tarifa upravnih akata i postupaka za privatne osobe mora biti pravična i razumna; 
- precizira da upravni akti moraju biti sročeni jednostavno, jasno i razumljivo, a pojedinačni upravni akti obrazloženi, činjenično i pravno;

- određuje da svi upravni akti moraju biti objelodanjeni točno i cjelovito, bilo naslovnicima, bilo svim zainteresiranima, a način i rok utoka preciziran;

- naglašava da upravni akti ne smiju imati retroaktivni učinak, osim u zakonski opravdanim, iznimnim okolnostima, te da se ne smije prigovoriti bilo kome, prije negoli su na odgovarajući način objavljeni;

- određuje da JU izvršava upravne akte iz svoje nadležnosti, a da privatne osobe moraju raspolagati razumnim rokom za izvršavanje svojih obveza iz upravnih akata, te da slučajevi prisilnog izvršenja moraju biti zakonski izričito predviđeni; i, na koncu,

- predviđa da pojedinačni upravni akti mogu biti izmijenjeni, odnosno njihovo provođenje odgođeno, ako to opravdavaju potrebe javnog interesa.

Treći dio Kodeksa VE bavi se samo dvama pitanjima:

- redovnog i izvanrednog utoka protiv - oportuniteta i zakonitosti - upravnih akata, na koje imaju pravo privatne osobe u slučajevima kad su njihova prava ili interesi izravno povrijeđeni, i to višoj upravnoj instanci i sudskom nadzoru;

- obeštećenja, u razumnom roku, za štetu koju su nezakoniti upravni akti, ili pogrešno postupanje javnih ovlaštenika nanijeli privatnim osobama.

Dodajmo, na koncu, da VE, kad god je pozvano da procijeni stupanj demokracije i pravne države zemalja kandidata i DČ, onda se ravna po tim kriterijima i normama.

\section{DIO: \\ DOBRA JAVNA UPRAVA U INSTITUCIJAMA EUROPSKE UNIJE}

Pravo na DJU jedno je od stvarnih, vremenski najnovijih prava građana EU, odnosno dužnosti DČ EU, pošto se javlja tek s Poveljom o temeljnim pravima, ${ }^{13}$ koja je stekla ugovornu i zakonsku snagu primarnog prava EU tek 1. prosinca 2009. godine, sa stupanjem na snagu Lisabonskog ugovora. ${ }^{14}$ Njegovo „sazrijevanje“ je ipak mnogo starije, budući da su neki aspekti prava na DJU postojali već u prethodnim ugovorima, koji su gradili EU, a Sud pravde EU se u svojoj jurisprudenciji, već od 60-tih godina, a naročito od 1991. godine, pozivao

13 Čl. 6. Ugovora o funkcioniranju EU određuje da Povelja o temeljnim pravima EU ,od 7. prosinca 2000. godine, kako je prilagođena u Strasbourgu 12. prosinca 2007 ... ima istu pravnu snagu kao Ugovori“. Povelju je iniciralo Europsko vijeće u Kölnu, u lipnju 1999., a prihvtilo ju je isto Vijeće na sastanku u Nici, u prosincu 2000. godine, ali kao pravno neobvezujući tekst. Tek je Lisabonski ugovor dao pravno obvezujuću snagu Povelji.

14 Čl. 6. Ugovora o EU. 
na neka od prava na DJU kao na polog općih načela prava demokratskih država. ${ }^{15}$ Konvencija, koja je sastavljala Povelju, nalazila se pred nizom prava i nije joj bilo lako odabrati ona prava koja su bliža djelatnostima i ovlastima Unije.

Pravo na DJU svojevrsni je pendant prava na dobro i pravedno suđenje, koje ozakonjuje Europska konvencija o ljudskim pravima, navlastito u svom čl. 6. To je pravo ujedno i značajan korak u smjeru izgradnje suvremenih ,upravnih demokracija“. ${ }^{16}$ Podsjetimo da već Maastrichtski ugovor (2002.) inzistira na potrebi da Unija bude „što bliža građanima“, te promovira načela supsidijarnosti i transparentnosti. Osim toga, taj Ugovor ustanovljuje institut Europskog posrednika, te na taj način omogućuje da se načela DJU poštuju u odnosima građana i pravnih osoba s institucijama EU.

Ono što je ubrzalo „sazrijevanje“ prava na DJU u okviru EU jest isto tako proširivanje njezinih nadležnosti, od onih isključivih, preko podijeljenih do potpornih. Važno je ovdje odmah naglasiti da se pravo na DJU ne odnosi samo na ograničeno postupanje „,centralne“ JU Unije, nego nadasve na „dekoncentriranu JU Unije“, a to su nacionalne JU koje izvršavaju politike, odluke i pravo Unije.

Danas se pravo na DJU u okviru EU temelji ne samo na pravnim formulacijama čl. 41 Povelje o ljudskim pravima Lisabonskog ugovora i na jurisprudenciji Suda pravde EU, nego i na konkretnoj djelatnosti Europskog posrednika, instituciji Unije koje je utemeljio Maastrichtski ugovor iz 1992. godine. I, na koncu, pravo na DJU temelji se i na standardima Europskog kodeksa o dobrom ponašanju u javnoj upravi EU, koji je Europski parlament usvojio u rujnu 2001.

\section{Pravo na dobru javnu upravu u Povelji o temeljnim pravima}

Članak 41. Povelje o temeljnim pravima lisabonskog Ugovora o funkcioniranju Europske unije pod naslovom Pravo na dobru upravu određuje sljedeće:

„1. Svatko ima pravo da institucije, tijela, uredi i agencije Unije njegove predmete obrađuju nepristrano, pravično i u razumnom roku.

2. Ovo pravo uključuje:

(a) pravo svake osobe na saslušanje prije poduzimanja bilokakve pojedinačne mjere koja bi na nju mogla nepovoljno utjecati;

(b) pravo svake osobe na pristup svojem dossieru, uz poštovanje zakonitih interesa povjerljivosti te profesionalne i poslovne tajne;

(c) obvezu uprave da obrazloži svoje odluke.

15 Tako npr. načelo pravičnog i promptnog rješavanja upravnih predmeta, kao i nepristranog postupanja. Jednako tako su bili od ranije priznata „opća načela prava“, kao što su načelo jednakosti, pravna sigurnost, podvrgnutost JU pravu, pravo na sudsku instancu i kontradiktoran postupak.

16 V. zbornik Commentary of the Charter of Fundamental Rights of the European Union i izd. Ludwig Boltzmann Institut für Menschenrechte, Beč, 2006. 
3. Svaka osoba ima pravo da joj Unija nadoknadi svaku štetu koju uzrokuju njezine institucije ili njezini službenici pri obavljanju svojih dužnosti, u skladu s općim načelima zajedničkima pravnim sustavima država članica.

4. Svaka se osoba može pisanim putem obratiti institucijama Unije na jednom od jezika Ugovorâ i mora dobiti odgovor na istom jeziku."

Najprije valja primijetiti da, premda čl. 41. spada u Glavu V. Povelje, kojoj je naslov Prava građana EU, tim se člankom pravo na DJU podjeljuje „svakome“, tj. svim osobama, fizičkim i pravnim, državljanima EU, ali i nedržavljanima EU koji zakonito borave na području Unije.

Riječ je, dakle:

- najprije, u stavku 1. o načelnom pravu svakoga na nepristrano, pravično $i$ u razumnom roku postupanje institucija Unije u njegovim stvarima,

- a zatim i o četiri prava, odnosno dužnosti, koja se tiču:

o s jedne strane, pravila i načela postupanja: biti saslušan i imati pravo pristupa svom dossieru, što unosi dimenziju kontradiktornosti postupka,

o s druge, dužnosti obrazlaganja svih upravnih odluka,

o s treće, prava na obeštećenje, za štetu koju je proizvela upravna odluka, a

o s četvrte, prava obraćanja institucijama Unije na jednom od služenih jezika Ugovora i dobivanja odgovora na tom jeziku.

Međutim, ova prava ne smiju se promatrati izolirano od drugih prava što ih Povelja jamči, a to su posebice pravo na pristup dokumentima EU (čl. 42), ili pravo na učinkovito pravno sredstvo / priziv (recours effectif). Tako npr. Sud pravde EU ispituje i sankcionira slučajeve nedovoljnog motiviranja upravnih odluka i pravnih norma u svjetlu načela razmjernosti i supsidijarnosti, što često potiče institucije EU na preobilno motiviranje.

Prava iz čl. 41/2 (a) i (b) odnose se, dakle, najprije na kontradiktorni aspekt postupka, koji je „temeljno načelo postupovnog prava“, kako to u više navrata naglašava Sud pravde EU, ${ }^{17}$ a zatim i na dužnost obrazlaganja upravnih odluka (c). Stavak 3. propisuje dužnost naknade štete koja nastane zbog djelovanja institucija ili službenika EU, dok stavak 4. štiti pravo ravnopravnog korištenja svih službenih jezika EU u obraćanju institucijama Unije, kao i pravo dobivanja odgovora na korištenom jeziku.

Što se tiče prava biti saslušan, ,prije poduzimanja bilo kakve pojedinačne mjere koja bi na nju mogla nepovoljno utjecati“" na određenu osobu (st. 2 (a)), a ne u svim slučajevima (nepovoljnim i povoljnim), pod francuskim je utjecajem - Guya Braibanta, državnog savjetnika - i u duhu francuske upravne tradicije,

17 V. izvor naveden u bilješci 16, Commentary..., str. 330. 
prihvaćeno to, restriktivno rješenje. ${ }^{18}$ Ipak i takvo, ono je u duhu temeljnog prava na obranu. Pravo pristupa ,svakoga... svom dossieru“ (st. 2 (a)) spada isto tako u postupovna pravila otvorenosti i jednakosti - koja je neophodna za uspješnu kontradiktornost - pa omogućuje svakoj osobi da ocijeni treba li joj ili ne pravna pomoć u vlastitim predmetima.

Načelo „obrazlaganja odluka“ / upravnih akata (c) duga je praksa u tradiciji EU, pa čak i obveza iz Ugovora ${ }^{19}$ (EEZ), pošto su institucije Unije, još od vremena EEZ dužne obrazlagati opće, sekundarne pravne izvore EEZ-uredbe, smjernice i odluke i to u svrhu dobrog razumijevanja tih izvora prava.

Pravo na obeštećenje za ,štete koju uzrokuju njezine institucije ili njezini službenici pri obavljanju svojih dužnosti" iz stavka 3. postojalo je isto tako već od Ugovora o EEZ (čl. 288), pa figurira i u čl. 340. važećeg Ugovoru ofunkcioniranju Europske unije (UFEU) i to kao „opće načelo prava država članica“, što potvrđuje i slovo ovog stavka.

Pravo na korištenje svih ,jezika Ugovorâ ${ }^{6}$ u obraćanju institucijama Unije i pravo na dobivanje odgovora na jeziku obraćanja, iz stavka 4., ustanovljuje potpunu jezičnu jednakost, jedinstvenu u međunarodnim organizacijama, što, uostalom, predviđa još i čl. 22. Povelje, ${ }^{20}$ a moguće je smatrati da to pravo izvire na određeni način i iz načela nediskriminacije (čl. 21).

\section{Prava, dužnosti i djelovanje Europskog posrednika - Ombudsmana}

Europskog posrednika, kao instituciju-osobu koja djeluje i posreduje kao „odvjetnik javnosti“, te se bavi odnosima između građana i institucija EU, utemeljio je Maastrichtski ugovor iz 1992. godine kao jednu od bitnih poluga nadzora i ostvarivanja prava na DJU u EU. U Lisabonskom ugovoru čl. 228. UFEU-a ovlašćuje europskog posrednika da istražuje pritužbe na slučajeve lošeg upravljanja svih institucija, organa i organizama Unije (u daljem tekstu: ,institucije Unije /EU“) osim Suda pravde EU i to samo u odnosu na njegove pravosudne ovlasti / funkciju. EP o svojim nalazima ima dužnost jednom godišnje izvještavati Europski parlament. EP nema pravo istraživati moguće loše postupanje i djelovanje nacionalnih i lokalnih JU DC.

Europskog posrednika bira svakih pet godina novi sastav Europskog parlamenta i on može biti ponovno biran za tu funkciju. U svom radu EP je potpuno nezavisan i nitko - ni institucije EU, ni DČ - nema pravo davati mu bilo kakve naputke ili naredbe (čl. 228/3 UFEU-a).

Postoje dva načina pokretanja postupaka istražnog djelovanja EP-a. Po prvom, EP-u se mogu obratiti, i to besplatno, ne samo građani i pravne osobe Unije, nego i sve druge fizičke i pravne osobe koje legalno borave na području EU.

18 V. Jean Paul Jacquet: Le droit à une bonne administration dans la charte des droits fondamentaux de l'Union européenne, in Revue française d'administration publique, 2001/1 (n 137-138).

19 Čl. 288 Ugovora Europskih ekonomskih zajednica, a danas čl. 296. Ugovora o funkcioniranju EU.

20 Kao i čl. 20/2, (d) UFEU-a. 
Ovo pravo obraćanja jest jedno od temeljnih prava zajamčenih Poveljom ${ }^{21} \mathrm{i}$, što je značajno, nije potrebno da osoba koja se žali bude osobno zainteresirana u stvari / postupanju na koje se žali. Po drugom, EP ima pravo i dužnost i sam, po vlastitom nahođenju, istraživati odnose institucija EU. U oba slučaja EP provodi istrage i, kad ustanovi nepravilnosti, obraća se odnosnoj instituciji i traži od nje odgovor i reakciju: ispravljanje nepravilnosti ili objašnjenje koje niječe nepravilnost. Nakon toga, EP obavještava Europski parlament, odnosnu instituciju i osobu koja je podnijela pritužbu o ishodu svoje istrage. EP isto tako svake godine obavještava Parlament o rezultatima svojih istraga. ${ }^{22}$

EP nije sudac i njegove preporuke nemaju pravno obvezujuće značenje. On nastoji utjecati na institucije EU kad smatra da su one pogriješile u svom upravnom postupanju. Njegova snaga izvire iz moralnog autoriteta, koji uživa ta institucija, a koji se temelji na uvjeravanju, na objavljivanju nalaza, kritika i preporuka, kao i na nastojanju postizanja kompromisa koji ispravljaju loše funkcioniranje institucija EU. EP može, iznimno, kad ne uspijeva privoliti pojedinu instituciju na poštovanje norma DJU, podastrijeti Europskom parlamentu i „,naročita izvješća“ s ciljem da Parlament donese „rezuoluciju“ u smislu njegovih preporuka.

Iza ove „osobne institucije“, ovlasti koje su do sada obnašale samo tri osobe, ${ }^{23}$ stoje u minulih 20 godina tisuće predmeta i veliko iskustvo istraživanja i provjere upravnog rada institucija EU. Temeljem tog rada i iskustva, EP je u lipnju 2012. godine, nakon javnih konzultacija, objavio sažetak izvanpravnih, etičkih pravila i uobličio ih u pet načela javnih služba koje trebaju voditi funkcionare EU u njihovu djelovanju:

- Zauzetost u odnosu na Uniju i njezine građane: funkcionari Unije iznose svoje prijedloge i donose odluke upravo u svrhu zaštite tih interesa;

- Integritet, koji znači ne samo poštovanje pravnih norma i izbjegavanje sukoba interesa, nego i odbijanje bilo kakvih pokušaja utjecaja i „darova“;

- Objektivnost, koja znači nepristranost i uvažavanje svih argumenata i mišljenja, te spremnost na priznanje i ispravljanje pogrešaka;

- Poštovanje drugoga, i službenika Unije i građanina, što se iskazuje kroz uslužnost, pristojnost, duh suradnje, promptnost u postupanju, ali i jasan i jednostavan rječnik / govor, koji nestručnjaci mogu razumjeti; i, na koncu, još i

${ }_{21}$ Čl. 43. Povelje, pod naslovom Europski ombudsman, određuje sljedeće: „Svaki građanin Unije te svaka fizička osoba koja prebiva ili pravna osoba sa sjedištem u nekoj državi članici ima pravo prijaviti Europskom ombudsmanu slučajeve nepravilnosti u postupku institucija, tijela, ureda ili agencija Unije, osim Suda Europske unije kad on obavlja svoju sudbenu dužnost."

22 V. čl. 228/1 UFEU-a.

23 Od 2013. godine ovu funkciju obnaša Irkinja Emily O'Railly, koja je prije toga bila irska Posrednica, a njoj su prethodila samo dva EP-a: Finac Jacob Söderman (1995. - 2003.) i Grk P. Nikiforos Diamandouros (2003. - 2013.), isto tako Posrednici u svojim zemljama prije mandata EP-a. 
- Transparentnost, koja se očituje u odgovarajućim „pisanim tragovima“ i registrima svih aktivnosti europske JU, kao i, posljedično, u pravu građana na uvid u te dokumente i postupke.

EP se u svom djelovanju, dakle, ne ograničava isključivo na zaštitu prava „prebivatelja“ u EU na DJU, nego postaje promicatelj naročite, upravne moralnosti JU u EU i konceptor deontološke „doktrine“ JU EU. Osim toga, EP je bio konceptor i redaktor Europskog kodeksa o dobrom ponašanju u upravi EU.

\section{Europski kodeks o dobrom ponašanju u javnoj upravi}

Već je rečeno da EP nema ovlast donošenja pravno obveznih odluka u svom posredovanju i svojim preporukama i inicijativama, pa tako ni Europski kodeks o dobrom ponašanju u javnoj upravi EU (EK-EU) nije obvezni pravni instrument. EP postupa, dakle, u skladu s pravom EU, jurisprudencijom Suda pravde EU i, na prvom mjestu, s Poveljom, ali isto tako i s već navedenim Kodeksom, donošenje kojeg je sam inicirao još 1998. godine, a predložio Europskom parlamentu sljedeće godine. Pri tome se EP vodio primjerima upravnog prava DČ.

Prijedlog i nacrt Kodeksa odobrio je Europski parlament svojom rezolucijom od 6. rujna 2001. godine, ${ }^{24}$ kojom je naložio da institucije EU poštuju Kodeks u svojim odnosima s građanima / „sa svakim“ u EU. Rezultat tog zahtjeva bio je da su, u skladu s načelima relativne autonomije, pa vjerojatno i određene supsidijarnosti, institucije Unije uspostavile vlastite kodekse, po vlastitim specifičnim potrebama i inspirirajući se u tome Europskim kodeksom (EK) EP-a. Europska komisija je međutim odbila prijedlog EP-a, da Kodeks bude prihvaćen „uredbom“, tj. najjačim pravnim sredstvom ,deriviranog prava“ Unije. Zbog toga Kodeks EU, sam po sebi, i ne predstavlja zbirku „subjektivnih“ javnih prava, kao što su to prava iz čl. 41. Povelje, premda precizira neka od tih prava. On, naravno, uključuje određena pravna načela, neka od ,subjektivnih“ javnih prava koja jamče druge, pravno obvezujuće norme EU, ali on formulira nadasve ne/izvanpravna pravila, najčešće deontološke naravi.

Pravila iz Kodeksa EU ne smiju biti shvaćana kao nekakva dodatna prava, povrh onih sadržanih u tekstu Ugovora ili deriviranog prava.

Jedina institucija Unije koja je objavila vlastiti kodeks jest Europska komisija, ali on sadrži samo norme obveznog postupanja Komisije, koje štite građane, pa se samim tim na njih mogu pozivati osobe koje smatraju da im je ta zaštita uskraćena.

Kodeks pridonosi definiranju DJU institucija EU i u početku imao je tri cilja: prvo, definirati kriterije po kojima je EP mogao procjenjivati radi li se u pojedinim pritužbama o lošem upravljanju institucija EU; drugo, opskrbiti institucije „,vodičem“ za njihove odnose s građanima i, treće, informirati građane o njihovim

${ }^{24}$ Nije jasno proističe li to odobravanje Kodeksa EU iz ovlasti Parlamenta po čl. 228/4. UFEU-a koji stipulira sljedeće: „Europski parlament uredbama, na vlastitu inicijativu, u skladu s posebnim zakonodavnim postupkom, nakon što zatraži mišljenje Komisije i uz suglasnost Vijeća, utvrđuje pravila i opće uvjete kojima se uređuje obavljanje dužnosti Europskog ombudsmana." 
pravima u odnosima s JU EU. ${ }^{25}$ Redakcija Kodeksa EU ukazuje isto tako na činjenicu da se on u pravilu obraća službenicima EU, a ne samim institucijama.

Kodeks sadrži, uz tri članka opće naravi, još i 24 druga pravila, koja su već u najvećoj mjeri bila predmetom ovog prikaza. U tri članka opće naravi, Kodeks EU proklamira dužnost svih - i stalnih i povremenih,pa čak i stručnjaka i stažista) - službenika EU da se u svojim odnosima s javnošću pridržavaju Kodeksa EU. Nakon tih uvodnih odredaba, Kodeks proglašava načela kojima se imaju voditi službenici EU u odnosima s građanima koja su već u najvećoj mjeri bila tretirana u ovom prikazu. To su sljedeća načela:

- Zakonitost: pravna pravila i postupci prava EU

- Odsutnost diskriminacije po bilo kojoj osnovi i jednakosti tretmana

- Razmjernost i pravično ravnovjesje između interesa privatnih osoba i javnog interesa

- Odsutnost zloporabe prava, odnosno djelovanja bez pravne osnove i mimo javnog interesa

- Nepristranost i nezavisnost, tj. odsutnost subjektivnosti i arbitrarnosti

- Objektivnost i isključivanje svih nerelevantnih elemenata

- Legitimno povjerenje, koherentnost i savjeti građanima

- Pravičnost, u smislu nepristranosti i razboritosti

- Uljudnost, kao pristojnost i uslužnost

- Odgovori na podneske građana, nevladinih udruga i pravnih osoba na jeziku podnesaka

- Potvrda primitka pritužbe i naznaka odgovornog službenika

- Obveza prosljeđivanja nadležnoj službi ili instituciji za pogrešno upućene pritužbe i podneske i obavijesti o tome podnositelju pismena

- Pravo biti saslušan i iznijeti svoje primjedbe u slučajevima odluka koje se tiču prava i obveza pojedinih osoba

- Razuman rok za donošenje odluka, a najkasnije dva mjeseca od podneska; u protivnom, promptno obavještavanje podnositelja

- Obveza obrazlaganja odluka: razloga, odlučujućih činjenica i pravne osnove

- Upućivanje na vrste mogućeg priziva i odgovorne instance, kao i pritužbe EP-u

- Pismeno promptno obavještavanje o odluci

- Zaštita podataka osobne naravi u skladu s uredbom CE br. 45/2001 Europskog parlamenta i Vijeća od 18. prosinca 2001. godine i savjeti građanima

- Zahtjevi za informacijama građanima te jasni i razumljivi odgovori i upute

25 V. prikaz Joqne Mendes pod naslovom „La bonne administration en droit communautaire et le code européen de bonne conduite administrative" u Revue française d'administration publique, 2009/3 (n¹31). 
- Zahtjevi za javni pristup dokumentima u skladu s uredbom CE br. 1049/2001.

- Držanje registara podnesaka i odgovora

- Informiranje javnosti o Kodeksu EU, elektronski i u obliku brošure

- Pravo žaliti se EP-u u skladu s čl. 228. UFEU-a

- Dužnost preispitivanja, svake dvije godine, od strane svih institucija EU, načina na koji primjenjuje Kodeks EU

\section{ZAKLJUČNE NATUKNICE}

Vrsnoća rada JU i njezino služenje građanima, kao i osiguranje suverenih / regalnih funkcija država i međunarodnih zajednica, sve je više predmetom konceptualizacije pravnih, etičkih, moralnih i deontoloških norma i standarda. Kako je na savjetovanju o Upravnim postupcima u EU naglasio prošle godine potpredsjednik francuskog Državnog savjeta, Jean-Marc Sauvé, odnosi građana i javne uprave doživljavaju u novije doba značajnu evoluciju, koja se kreće od težnje za postizanjem standarda „upravne demokracije“ - i u te promjene ulazi ne samo Povelja s navedenim odredbama nego i institucija Europskog posrednika (EP) - i dolazi u EU i u DČ, sve do jačanja tendencije za kodificiranjem upravnih (nesudskih) postupovnih pravila i standarda, kao i upravne kulture služenja građanima. ${ }^{26}$ Ono, što ipak još uvijek nedostaje, a što zahtijevaju posebice „podijeljene ovlasti“ EU i DČ, to su postupovna pravila i norme za te „mješovite“ upravne postupke, u kojima surađuju upravne strukture EU i nacionalne uprave DČ, bilo kao „dekoncentrirane JU“ EU, bilo kao samostalne JU DČ.

26 V. izlaganje J-M. Sauvéa na 2. okruglom stolu, pod naslovom Les procédures applicables à l'édiction des décisions administratives individuelles, na konferenciji koju je u Bruxellesu 3. listopada 2014. organizirao Europski posrednik. G. Sauvé, koji je i sam sudjelovao, a nakon toga pružao stalnu podršku Hrvatsko-francuskim pravnim i upravnim danima, podsjetio je tom prigodom na konstataciju pariškog profesora prava Jeana Rivera da načelo DJU teži, „,ne pasivnom podvrgavanju građanina odluci koja mu se, donesena u tajnosti, nameće samom svojom silom, nego mnogo više... razboritim prihvaćanjem koje podanika pretvara u građanina.“ 


\section{RIGHT TO GOOD PUBLIC ADMINISTRATION - in the context of European Integration -}

This title inevitably makes us think of human rights as if it is insisting on some new human and citizen rights such as for example ,the right to water", which was the subject of a civil law creating initiative last year before the European Commission.

The right to „good public administration "is often identified with the right to ,good management". So, in the introduction it will be necessary to differentiate between these two concepts. Then „good public administration "will be dealt with; its principles and deontology in two European integrations or member states who are Croatia and France. These are primarily the old political integration of the European Council and then the more recent ones mainly including economic integration which is the European Union. Therefore, these two concepts will firstly be observed as to their definition in international organisations and in the internal plan of democratic states.

Key words: right to public public administration, european integration, member state 